\title{
Establishing the relationship of soil nitrogen immobilization to cereal rye residues in a mulched system
}

\author{
Alwyn Williams • M. Scott Wells • David A. Dickey • Shuijin Hu • Jude Maul • \\ Daniel T. Raskin • S. Chris Reberg-Horton • Steven B. Mirsky
}

Received: 16 October 2017 / Accepted: 9 January 2018 /Published online: 12 March 2018

(C) The Author(s) 2018. This article is an open access publication

\begin{abstract}
Background and aims Soil nitrogen $(\mathrm{N})$ immobilization from cover crop residues may help suppress weeds. We established a gradient of cereal rye shoot biomass to determine the extent that soil $\mathrm{N}$ can be immobilized and its effect on redroot pigweed (Amaranthus retroflexus L.). Methods A microplot study was conducted in no-till cereal rye (Secale cereale L.) - soybean (Glycine max L. (Merr.)) systems at two sites in eastern USA. Microplots received 0, 2000, 5000, 8000, 12,000 or
\end{abstract}

Responsible Editor: Cindy Prescott.

A. Williams

School of Agriculture and Food Sciences, The University of Queensland, QLD, Gatton 4343, Australia

M. Scott Wells $(\bowtie) \cdot$ D. T. Raskin

Department of Agronomy and Plant Genetics, University of

Minnesota, St. Paul, MN 55108, USA

e-mail: mswells@umn.edu

D. A. Dickey

Department of Statistics, North Carolina State University, Raleigh, NC 27695, USA

S. $\mathrm{Hu}$

Department of Plant Pathology, North Carolina State University, Raleigh, NC 27695, USA

J. Maul · S. B. Mirsky

Sustainable Agriculture Systems Laboratory, USDA-ARS,

Beltsville, MD 20705, USA

S. Chris Reberg-Horton

Department of Crop Science, North Carolina State University,

Raleigh, NC 27695, USA
$15,000 \mathrm{~kg} \mathrm{ha}^{-1}$ of cereal rye shoot biomass, and were injected with two $\mathrm{mg}^{15} \mathrm{~N} \mathrm{~kg}^{-1}$ soil $5 \mathrm{~cm}$ below the soil surface. Pigweeds were sown and allowed to germinate. Results Maximum rates of cereal rye shoot decomposition were observed at $\geq 5000 \mathrm{~kg} \mathrm{ha}^{-1}$. Although cereal rye shoot $\mathrm{N}$ declined, shoots became enriched with ${ }^{15} \mathrm{~N}$, indicating fungal transfer of soil $\mathrm{N}$ to shoots. Soil inorganic $\mathrm{N}$ declined by an average of $5 \mathrm{~kg} \mathrm{~N}^{-1}$. Pigweed tissue $\mathrm{N}$ and biomass were reduced in the presence of cereal rye. The magnitude of pigweed $\mathrm{N}$ reduction was similar across all shoot application rates.

Conclusions We found weak evidence for a cereal rye shoot-based $\mathrm{N}$ immobilization mechanism of weed suppression. Our results indicate $\mathrm{N}$ immobilization may be primarily due to root residues.

Keywords Secale cereale L. Weed suppression · Cover crop mulch $\cdot{ }^{15} \mathrm{~N}$ stable isotope $\cdot \mathrm{N}$ immobilization .

Residue decomposition

\section{Introduction}

Demand for organic soybean (Glycine max L. (Merr.)) for both feedstock and human consumption has grown continuously over the past decade. Increased demand has driven commodity prices to near record highs, and in many cases organic soybean sells for twice that of conventional soybean (McBride et al. 2015). However, organic soybean production incurs considerably higher operational costs than conventional soybean production, arising primarily from higher fuel costs for weed 
management (McBride and Greene 2009). These higher operational costs have the potential to reduce the economic and environmental sustainability of organic soybean production systems, pointing to the need to develop alternative methods of organic weed control.

Weeds in organic soybean systems are typically managed through frequent and intensive cultivation events. While effective for weed control, excessive soil cultivation can lead to compaction of the sub-soil layer, increase the risk of water and wind erosion, and stimulate mineralization of soil organic carbon (C) (Håkansson and Reeder 1994; Grandy and Robertson 2007; Montgomery 2007). Increased disturbance also contributes to the degradation of soil aggregates and loss of $\mathrm{C}$ storage capacity (Beare et al. 1997; Six et al. 2006). Moreover, frequent tillage entails elevated energy consumption and higher labor costs (Bernstein et al. 2011; Mirsky et al. 2012).

Weed suppressive cover crop mulches are underutilized in organic soybean production systems, yet have the potential to increase the sustainability of these systems. Several studies have demonstrated the effectiveness of cover crop mulches, produced via a roller-crimper, for weed control in organic systems (Reberg-Horton et al. 2012; Wells et al. 2013; Mirsky et al. 2013). A roller-crimper is a ground-driven implement that physically terminates near-mature cover crops before no-till cash crop planting, leaving a surface mulch of cover crop shoot residues as well as intact belowground root residues (Ashford and Reeves 2003; Reberg-Horton et al. 2012; Wells et al. 2013). Used for many years in Brazil (Derpsch et al. 1991), roller-crimping cover crops in annual row-crop systems increased in popularity in the US following improvements in roller-crimper design (Kornecki et al. 2009).

The primary mechanisms behind the weed suppressive attributes of roller-crimped (roll-crimped) cover crops are both physical and chemical in nature. Physically, cover crop residues provide a restrictive barrier that alters the soil surface microclimate (i.e., soil moisture and light), thus inhibiting weed seed germination (Teasdale and Mohler 2000; Webster et al. 2016). This mechanism requires sufficient cover crop biomass production to achieve optimum weed suppression. In the case of organic soybean production, $8000-9000 \mathrm{~kg} \mathrm{ha}^{-1}$ rye dry matter biomass has been reported as being the minimum threshold for acceptable weed control in the eastern US (Reberg-Horton et al. 2012; Mirsky et al. 2013). Chemically, cover crop residues suppress weeds through the release of phytotoxic allelopathic chemicals (Reberg-Horton et al. 2005).

Recent research suggests that a third control mechanism of nitrogen $(\mathrm{N})$ limitation may also play an important role in weed suppression (Kumar et al. 2008, 2011). Reduced plant-available nitrogen and subsequent $\mathrm{N}$ stress in summer annual broadleaf weeds (Amaranthus retroflexus L.), was reported in organic soybean systems that utilized roll-crimped cover crops (Wells et al. 2013). Lower plant-available $\mathrm{N}$ in high cover crop residue systems may contribute to and enhance overall weed suppression in these systems. While cover crop residueinduced $\mathrm{N}$ immobilization can limit $\mathrm{N}$ uptake by cash crops as well as weeds, leguminous cash crops such as soybean do not rely solely on plant-available soil $\mathrm{N}$ for growth, and consequently may not be impaired by $\mathrm{N}$ immobilization.

To our knowledge, weed suppression by $\mathrm{N}$ limitation due to cover crop root and shoot residues has not been investigated. There is, however, a sizable body of literature describing the effects of incorporating high $\mathrm{C}: \mathrm{N}$ ratio residues into the soil system and subsequent increases in N immobilization (Schomberg et al. 1994; Recous et al. 1995; Burgess et al. 2002; Jin et al. 2008). In forestry systems, $\mathrm{N}$ transfer from soil to surface residues accounted for total $\mathrm{N}$-immobilization in the forest litter layer during the first year of decomposition (Hart and Firestone 1991). Analogous Nimmobilization effects were reported when wheat straw residues (ranging from 40 to $80: 1 \mathrm{C}: \mathrm{N}$ ) were applied to soil surfaces (Holland and Coleman 1987; Schwendener et al. 2005), and fungal translocation of soil $\mathrm{N}$ to the surface residues was confirmed as one of the modes of $\mathrm{N}$-transfer (Frey et al. 2000). However, the concept of $\mathrm{N}$ limitation associated with high $\mathrm{C}: \mathrm{N}$ ratio cover crop residues is not fully characterized in an agricultural setting. The absence of such characterization limits opportunity to manage cover crops and microbial processes for enhanced weed suppression, and thus constrains potential improvements in agricultural sustainability.

Recent research on $\mathrm{N}$ dynamics associated with high biomass cover crop residues has confirmed $\mathrm{N}$ transfer from soil to aboveground residues, and provides partial confirmation of the hypothesized fungal translocation mechanisms (Frey et al. 2000; Wells et al. 2017). However, Wells et al. (2017) did not establish the optimal rate of cereal rye residue biomass for $\mathrm{N}$ immobilization, nor determine if the $\mathrm{N}$ immobilization event had a measurable 
response on escaped weeds in the system. We hypothesize that increased cereal rye biomass levels will result in greater immobilization of soil $\mathrm{N}$ into surface residues, thereby limiting plant-available $\mathrm{N}$ throughout the soil profile and increasing $\mathrm{N}$ stress in summer annual broadleaf weeds. The objective of this study was to characterize the magnitude of $\mathrm{N}$ immobilization from increasing rates of cereal rye shoot residue biomass, and the subsequent effect on soybean and pigweed biomass and $\mathrm{N}$ content.

\section{Methods}

Study locations

In 2011, a two site-year experiment was conducted at the Center for Environmental Farming Systems in Goldsboro (GOLD), North Carolina $\left(35.38291^{\circ} \mathrm{N}\right.$, $-78.035846^{\circ} \mathrm{W}$ ), and the USDA-ARS Beltsville Agricultural Research Center (BARC) in Beltsville, Maryland $\left(39.03269^{\circ} \mathrm{N},-76.928143^{\circ} \mathrm{W}\right)$. The soil type in GOLD was Wickham loamy sand (fine-loamy, mixed, semiactive, thermic Typic Hapludults) with 2 to $6 \%$ slope; at BARC the soil types were Codorus and Hatboro (mica bearing loamy alluvium), with 0 to $2 \%$ slope. Climate conditions over the experimental period are shown in Table 1.
Experimental design

Treatments consisted of six cereal rye shoot biomass application rates crossed with seven two-week destructive harvests (no replication) for a total of 42 treatment combinations including experimental controls. We prioritized establishing a response surface, where many factor levels of each treatment were considered more important for modeling purposes than replication of treatment combinations. The time factor is not a repeated measure in this study since each plot was randomly assigned a time at which it would be sampled and each experimental unit was sampled only once.

Prior to fall drilling of cereal rye (Secale cereale 'Wheeler'), the entire field, at both locations, was disked and field cultivated to remove any existing vegetation from the prior maize and clover hay crops at BARC and GOLD, respectively. Lime, phosphorus (P), and potassium $(\mathrm{K})$ were applied according to soil test before cereal rye planting. Cereal rye was drilled at a rate of $134 \mathrm{~kg}$ seed $\mathrm{ha}^{-1}$ on a $13 \mathrm{~cm}$ row spacing during midOctober for all treatments. Plots were fertilized in the fall with $30 \mathrm{~kg} \mathrm{~N} \mathrm{ha}^{-1}$ as urea ammonium nitrate (UAN) to ensure adequate $\mathrm{N}$ availability for early growth of the cereal rye cover crop.

The microplots consisted of 42 steel box frames that were $0.58 \mathrm{~m}^{2}$ (no boxes were assigned to the time $=0$ plots; Fig. 1). Before microplots were installed, the cereal

Table 1 Monthly precipitation and maximum, minimum and mean air temperature from May to October, 2011 in Beltsville, MD and Goldsboro, NC. 30-year mean values (1980-2010) are shown in parentheses

\begin{tabular}{|c|c|c|c|c|c|}
\hline \multirow[t]{2}{*}{ Location } & \multirow[t]{2}{*}{ Month } & \multirow[t]{2}{*}{ Precip. (mm) } & \multicolumn{3}{|c|}{ Monthly air temperature $\left({ }^{\circ} \mathrm{C}\right)$} \\
\hline & & & Maximum & Minimum & Mean \\
\hline \multirow[t]{7}{*}{ Beltsville, MD } & May & $64(110)$ & $24.7(23.6)$ & $14.1(11.3)$ & $19.4(17.4)$ \\
\hline & June & $70(94)$ & $29.8(28.7)$ & $18.4(16.8)$ & $24.1(22.7)$ \\
\hline & July & $70(100)$ & $32.7(30.9)$ & $21.1(19.4)$ & $26.9(25.2)$ \\
\hline & August & $316(83)$ & $29.8(30.1)$ & $19.3(18.6)$ & $24.5(24.3)$ \\
\hline & September & $248(104)$ & $25.5(26.1)$ & $17.0(14.3)$ & $21.3(20.2)$ \\
\hline & October & $113(93)$ & $18.7(19.8)$ & $8.5(7.3)$ & $13.6(13.6)$ \\
\hline & Mean & $294(97)$ & $26.9(26.5)$ & $16.4(14.6)$ & $21.6(20.6)$ \\
\hline \multirow[t]{7}{*}{ Goldsboro, NC } & May & $27(96)$ & $27.5(27.3)$ & $14.9(14.7)$ & $21.2(20.9)$ \\
\hline & June & $23(98)$ & $33.2(30.9)$ & $20.1(19.7)$ & $26.7(25.3)$ \\
\hline & July & $147(141)$ & $34.3(32.2)$ & $22.4(21.7)$ & $28.3(27.0)$ \\
\hline & August & $420(149)$ & $31.8(31.3)$ & $21.1(20.8)$ & $26.5(26.1)$ \\
\hline & September & $55(152)$ & $28.3(28.2)$ & $18.3(17.3)$ & $23.3(22.8)$ \\
\hline & October & $51(76)$ & $22.1(23.2)$ & $8.9(11.1)$ & $15.5(17.1)$ \\
\hline & Mean & 121 (119) & $29.5(28.9)$ & $17.6(17.6)$ & $23.6(23.2)$ \\
\hline
\end{tabular}


rye cover crop was terminated in early June (Zadoks 85 ) via a mower conditioner haybine. Average aboveground field biomass across both sites was $9400 \mathrm{~kg} \mathrm{DM} \mathrm{ha}^{-1}$, with C:N ratios of $68: 1$ and 48:1 for Beltsville and Goldsboro, respectively. Belowground cereal rye biomass was estimated to be $20 \%$ of total (aboveground and belowground) cereal rye biomass at termination, i.e., $2350 \mathrm{~kg}$ $\mathrm{DM} \mathrm{ha}^{-1}$ (Sheng and Hunt 1991; Bolinder et al. 2007; Patel et al. 2015). Haybined cereal rye shoots were removed from the experimental area and air-dried for oneweek. Following cereal rye shoot removal, 42 microplot boxes were installed directly into the cereal rye cover crop stubble to a depth of $40 \mathrm{~cm}$. Soybean (Maturity Group VI) was hand-sown at a rate of 370,650 seeds ha ${ }^{-1}$ with $76 \mathrm{~cm}$ row spacing. In addition, redroot pigweed (Amaranthus retroflexus L.) was sown on both sides of the soybean row. A one-time application of ${ }^{15} \mathrm{~N}$-enriched $\left(\mathrm{NH}_{4}\right)_{2} \mathrm{SO}_{4}$ solution (99.7 at.\%), at a rate of $3.31 \mathrm{~kg} \mathrm{~N} \mathrm{ha}^{-1}$, was uniformly injected using large gauge needles approximately $5 \mathrm{~cm}$ below the soil surface at soybean planting (i.e., zero days after planting, DAP). This low rate of $\mathrm{N}$ addition was used to provide an effective $\mathrm{N}$ label that would not perturb natural $\mathrm{N}$ dynamics. Following injection of ${ }^{15} \mathrm{~N}$, cereal rye shoot residues were applied to each microplot according to the prescribed rate.

Cereal rye shoot application rates consisted of 0 , $2000,5000,8000,12,000$, and $15,000 \mathrm{~kg} \mathrm{ha}^{-1}$ of aboveground DM. For the $0 \mathrm{~kg} \mathrm{ha}^{-1}$ shoot rate treatment, no residues were applied, creating a 'roots only' control that was intended to quantify $\mathrm{N}$ dynamics in the absence of surface residue but with root residues included (Fig. 1). An additional control treatment was created where neither cereal rye roots nor shoots were present, i.e., a fallow 'bare-ground' check. Bare-ground checks were maintained in a fallow state using herbicides beginning several months prior to soybean planting. Sampling events occurred $0,14,30,44,58,72$ and 86 days after planting (Fig. 1).

To assess ${ }^{15} \mathrm{~N}$ contamination to cereal rye shoots at injection, shoots from the 0 DAP microplot were applied and then removed after two to four hours; the collected material was evaluated for percent enrichment of ${ }^{15} \mathrm{~N}$. Cereal rye shoots were arranged away from regions where soybean and pigweed rows were seeded,

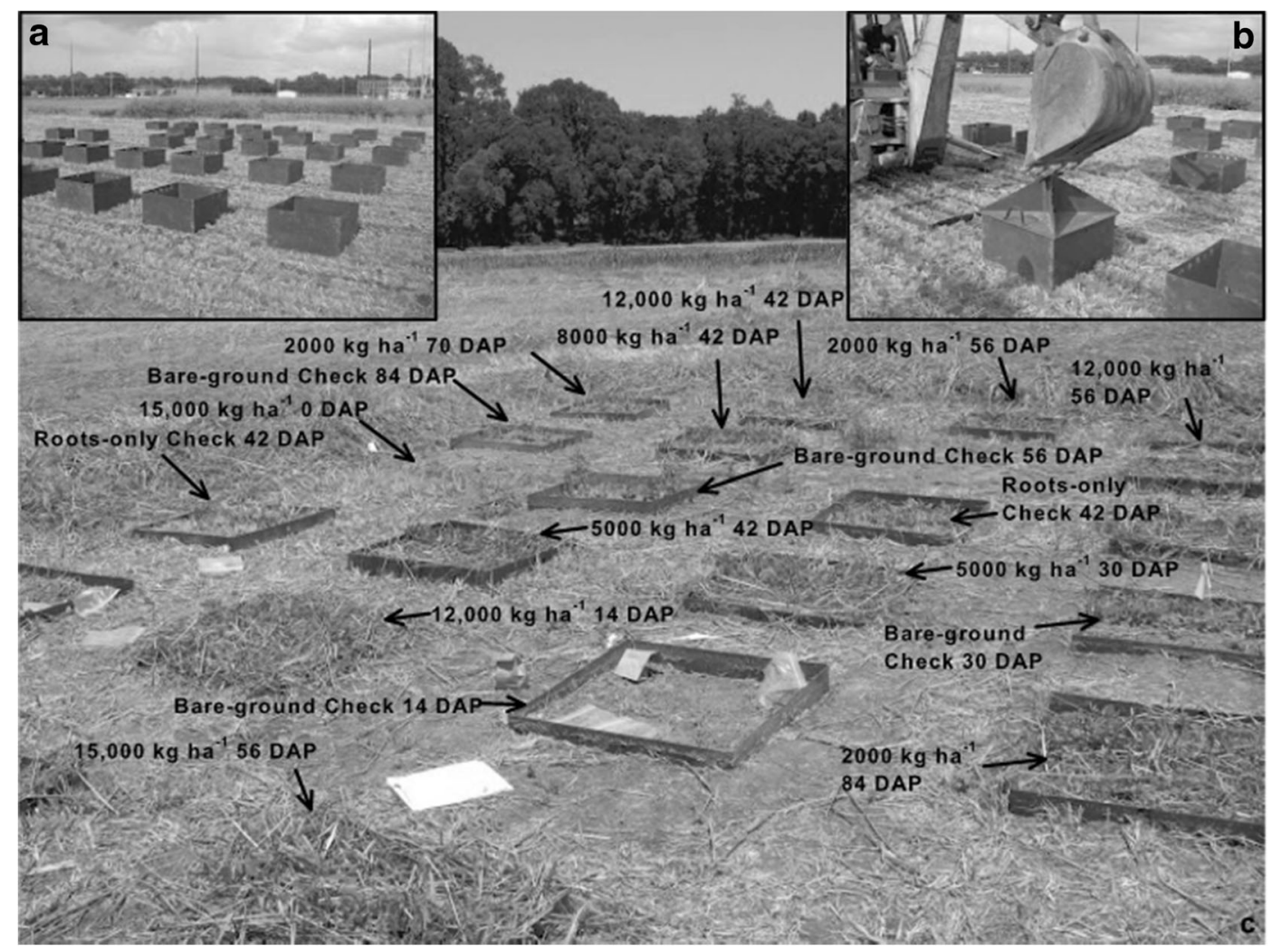

Fig. 1 Treatment assignment and layout corresponding with cereal rye residue rates and times associated with harvest (c). Top panels (a and b) show micro-plot boxes prior to installation and during installation. Goldsboro, North Carolina 
and were pinned down using landscape staples. This was done to prevent the cereal rye shoots from influencing light transmittance at the soil surface, as the focus of this project was to isolate the effects of $\mathrm{N}$ availability from physical effects (light, temperature, and physical occlusion). After emergence, pigweed was thinned to eight plants per microplot and all other emerged weeds were removed by clipping them at the soil surface with scissors. Microplots were irrigated weekly during the first five weeks of the trial at a rate simulating $1.3 \mathrm{~cm}$ rainfall per week (equivalent to $7.4 \mathrm{~L} \mathrm{H}_{2} \mathrm{O}$ microplot $^{-1}$ week $^{-1}$ ); afterwards, irrigation was administered at the same rate on an as-needed basis based on perceived plant moisture stress.

\section{Parameter assessments}

For each sampling event, the following soil and crop parameters were measured: cereal rye shoot biomass, soybean plant tissue $\mathrm{N}$, pigweed tissue $\mathrm{N}$, and soil extractable inorganic $\mathrm{N}(0-10 \mathrm{~cm}$ depth). Cereal rye shoots, as well as soybean and pigweed tissue, were collected from entire microplots and air-dried at $60{ }^{\circ} \mathrm{C}$ for $72 \mathrm{~h}$. Dried plant tissue was weighed, finely milled (i.e., ball-ground), and analyzed for total $\mathrm{N}$ by a PerkinElmer (Norwalk, CT) Model 2400 CHN elemental analyzer (Tu et al. 2006; Wells et al. 2013). Ballground plant tissue was also packed into $9 \times 5 \mathrm{~mm}$ tin capsules and sent to the Stable Isotope Facility at University of California, Davis to be analyzed for $\mathrm{N}$ isotope ratios using a PDZ Europa ANCA-GSL elemental analyzer interfaced to a PDZ Europa 20-20 isotope ratio mass spectrometer (Sercon Ltd., Cheshire, UK).

Soil inorganic $\mathrm{N}$ was monitored by collecting $16 \times$ $7.6 \mathrm{~cm}$ diameter cores $(0-10 \mathrm{~cm}$ depth$)$, arranged in a grid within each microplot. Bulk density and soil moisture were also assessed at each sampling interval. Soil samples were homogenized, wet-sieved $(2 \mathrm{~mm})$ to remove any plant material and rocks, and placed in cold $\left(4{ }^{\circ} \mathrm{C}\right)$ storage for transport. Soil inorganic $\mathrm{N}$ was extracted from $20 \mathrm{~g}$ of field moist sieved soil in $50 \mathrm{~mL}$ of $0.5 \mathrm{M} \mathrm{K}_{2} \mathrm{SO}_{4}$ shaken for $30 \mathrm{~min}$ on an orbital shaker (Hart et al. 1994; Frey et al. 2000). After samples had been shaken, the soil suspension was filtered with filter papers that had been preleached with $100 \mathrm{~mL}$ of $0.5 \mathrm{M}$ $\mathrm{K}_{2} \mathrm{SO}_{4}$ (Fisher Scientific Filter Paper Grade Q2); subsamples were analyzed for ammonium and nitrate on a Quick Chem 8000 Lachat (Keeney and Nelson 1982).
Statistical analysis

Data were first assessed by ANOVA to determine the presence of any significant site effects. Given the absence of statistically significant site effects, data from BARC and GOLD were pooled to improve robustness of our model fits. Model fitting was conducted utilizing exponential growth and decay equations in R 3.3.2 ( $\mathrm{R}$ Core Team 2016; Pinheiro et al. 2016). Cereal rye shoot decomposition and $\mathrm{N}$ loss were modeled for each biomass application rate with the following exponential decay equation:

$P_{t}=P_{0} \cdot e^{(-\lambda \cdot D A P)}$

Where $P_{t}=$ cereal rye shoot biomass or $\mathrm{N}$ content at time $t, P_{0}=$ cereal rye shoot biomass or $\mathrm{N}$ content zero days after soybean planting, $\lambda=$ decay constant, and $D A P=$ days after soybean planting. The decay constant, $\lambda$, was estimated for each cereal rye shoot application rate using nonlinear least squares.

Soybean and pigweed biomass $\mathrm{N}$ uptake were modeled across all cereal rye shoot application rates with the following exponential growth equation:

$Y_{t}=P_{r} \cdot e^{(\lambda \cdot D A P)}$

Where $Y_{t}=$ soybean or pigweed biomass $\mathrm{N}$ at time $t$, $P_{r}=$ cereal rye shoot biomass plus estimated belowground biomass zero days after soybean planting (fallow rate $=0 \mathrm{~kg} \mathrm{ha}^{-1}$ ).

Cereal rye shoot ${ }^{15} \mathrm{~N}$ and soil extractable inorganic $\mathrm{N}$ were modeled using the following response surface quadratic function:

$$
\begin{aligned}
Y_{t}= & \beta_{0}+\beta_{1} \cdot D A P+\beta_{2} \cdot P+\beta_{3} \cdot D A P \cdot P \\
& +\beta_{4} \cdot D A P^{2}+\beta_{5} \cdot P^{2}
\end{aligned}
$$

Where $Y_{t}=$ cereal rye shoot ${ }^{15} \mathrm{~N}$ or soil extractable inorganic N, $\beta_{0}=$ intercept, $\beta_{1-5}=$ regression coefficients, $P=P_{0}$ (for cereal rye shoot ${ }^{15} \mathrm{~N}$ accumulation; $P_{0}$ from Eq. 1) or $P=P_{r}$ (for extractable soil N; $P_{r}$ from Eq. 2). All model terms were retained regardless of statistical significance. For all modeled parameters, the effects of shoot application rates were assessed using ordinary least squares regression. 


\section{Results}

Cereal rye shoot biomass decomposition kinetics

Applied cereal rye shoots decomposed steadily over the 86 days of the experiment, with 55\% decomposition of shoot biomass occurring for each application rate (Fig. 2). While total decomposition levels were comparable, the rate of decomposition differed significantly $\left(F_{4,60}=17.00, P<0.001\right)$ between application rates (Fig. 2). At $2000 \mathrm{~kg} \mathrm{ha}^{-1}$ of shoot biomass, decomposition was slower compared with the 5000-15,000 kg $\mathrm{ha}^{-1}$ application rates, which did not differ statistically from one another. The decay constant, $\lambda$, increased from 0.008 for the $2000 \mathrm{~kg} \mathrm{ha}^{-1}$ rate to a maximum of 0.011 for the $5000 \mathrm{~kg} \mathrm{ha}^{-1}$ rate (Table 2).

Cereal rye shoot nitrogen dynamics

Cereal rye shoot $\mathrm{N}$ content declined over time across all shoot application rates, losing approximately $45 \%$ of initial $\mathrm{N}$ content by 86 days after soybean planting (Fig. 3). Decomposition rates and estimated decay constants did not differ across the different shoot application rates.

There was detectable enrichment of cereal rye shoots with ${ }^{15} \mathrm{~N}$ in all shoot application rates throughout the duration of the study, with ${ }^{15} \mathrm{~N}$ content averaging $0.031 \mathrm{~kg} \mathrm{ha}^{-1}$ by 86 DAP across all shoot application rates (Fig. 4). Translocation of ${ }^{15} \mathrm{~N}$ from the soil surface to shoots increased with shoot application rate $\left(t_{1,64}=\right.$ $1.90, P=0.06)$. At $86 \mathrm{DAP},{ }^{15} \mathrm{~N}$ content in the $2000 \mathrm{~kg}$ rate was $0.022 \mathrm{~kg} \mathrm{ha}^{-1}$ while ${ }^{15} \mathrm{~N}$ content in the $15,000 \mathrm{~kg}$ rate was $0.035 \mathrm{~kg} \mathrm{ha}^{-1}$ (Fig. 4).

The majority of the ${ }^{15} \mathrm{~N}$ applied was recovered in aboveground soybean tissues (Fig. 5). The proportion of ${ }^{15} \mathrm{~N}$ recovered in soybean tissues showed an increasing trend with the rate of cereal rye shoots applied, while ${ }^{15} \mathrm{~N}$ in pigweed showed a declining trend (Fig. 5). The recovery of ${ }^{15} \mathrm{~N}$ in soybean and pigweed at the highest shoot application rate appears anomalous relative to the overall trend, and exclusion of the highest rate shows the difference between soybean and pigweed trendlines to be significant $\left(t_{1,18}=2.11, P=0.05\right.$; Fig. 5$)$. The proportion of ${ }^{15} \mathrm{~N}$ recovered in cereal rye shoots did not differ statistically across shoot application rates.

Extractable soil inorganic nitrogen and plant responses

Extractable soil inorganic $\mathrm{N}$ content declined over time by approximately $78 \%$ of initial soil $\mathrm{N}$ content by 86 DAP across all shoot application rates (Fig. 6). While soil inorganic $\mathrm{N}$ declined with increasing shoot biomass $\left(t_{1,64}=2.49, P=0.01\right)$, the magnitude of the differences across shoot application rates was small (Fig. 6).

The rate of pigweed $\mathrm{N}$ uptake and biomass accumulation over the course of the experiment did not differ between any of the microplots containing cereal rye residues (Figs. 7 and 8). However, pigweed had greater rates of $\mathrm{N}$ uptake and biomass accumulation in the absence of cereal rye roots and shoots (pigweed tissue $\mathrm{N}: F_{1,72}=17.36, P<0.001$; pigweed biomass: $F_{1,58}=$ $10.75, P=0.002$ ). By $86 \mathrm{DAP}$, pigweed $\mathrm{N}$ in the bare-
Fig. 2 Exponential decomposition of cereal rye shoot biomass for each shoot application rate $\left(\mathrm{kg} \mathrm{ha}^{-1}\right)$. Points for each sampled day after planting are offset to reduce overlap

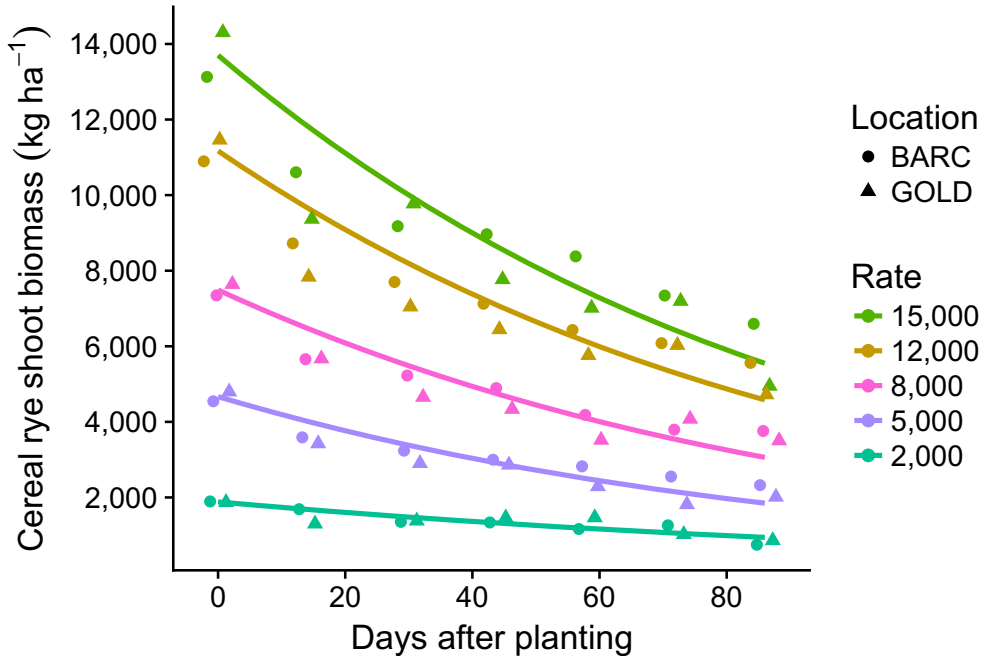


Fig. 3 Exponential loss of cereal rye shoot $\mathrm{N}$ for each shoot application rate $\left(\mathrm{kg} \mathrm{ha}^{-1}\right)$. Points for each sampled day after planting are offset to reduce overlap

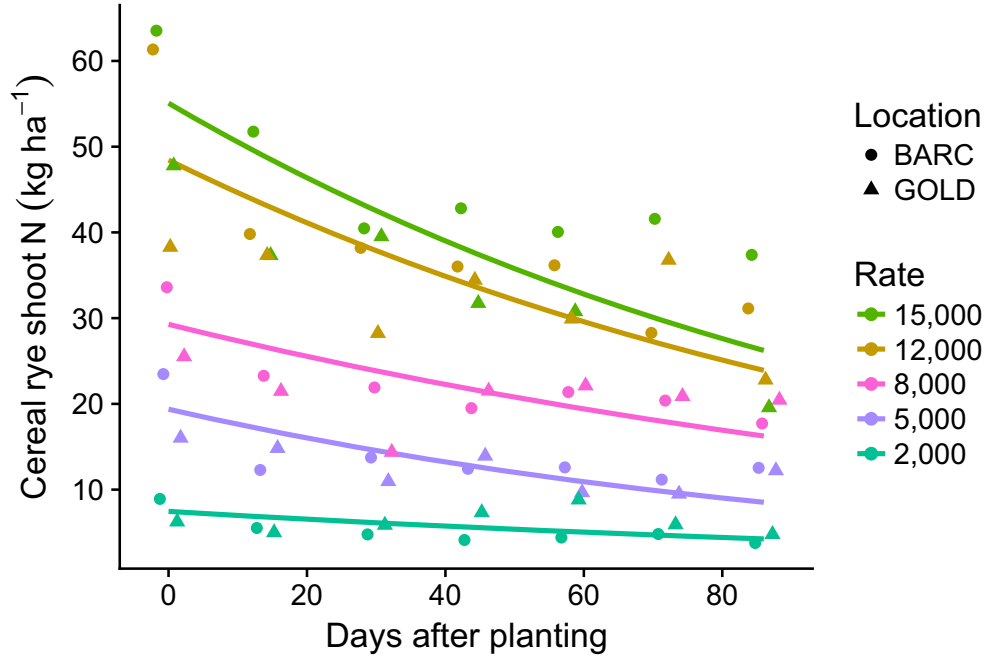

ground check increased to an average of $19 \mathrm{~kg} \mathrm{~N} \mathrm{ha}^{-1}$, compared to $3 \mathrm{~kg} \mathrm{~N} \mathrm{ha}^{-1}$ averaged across all cereal rye treatments (Fig. 7), and pigweed biomass reached $3505 \mathrm{~kg} \mathrm{ha}^{-1}$ in the bare-ground check compared with $583 \mathrm{~kg} \mathrm{ha}^{-1}$ averaged across all cereal rye treatments (Fig. 8). In contrast, soybean biomass (Fig. 9) and N uptake (data not shown) were not affected by the presence of cereal rye residues. By 86 DAP, soybean biomass averaged $9253 \mathrm{~kg} \mathrm{ha}^{-1}$, and $\mathrm{N}$ uptake averaged $83 \mathrm{~kg} \mathrm{ha}^{-1}$ across all treatments and controls.

\section{Discussion}

Contrary to our initial hypothesis, cereal rye shoot biomass rates did not drive system $\mathrm{N}$ dynamics in this study. Cereal rye shoot biomass decomposition was significantly affected by shoot application rate, but had limited impacts on soil $\mathrm{N}$ immobilization

Table 2 Estimated cereal rye shoot biomass decay constants $(\lambda)$ for each shoot application rate

\begin{tabular}{ll}
\hline $\begin{array}{l}\text { Cereal rye residue application } \\
\text { rate }\left(\mathrm{kg} \mathrm{ha}^{-1}\right)\end{array}$ & $\begin{array}{l}\text { Estimated decay constant } \\
(\lambda)\left(\text { day }^{-1}\right)\end{array}$ \\
\hline 2000 & 0.00805 \\
5000 & 0.01072 \\
8000 & 0.01042 \\
12,000 & 0.01036 \\
15,000 & 0.01053 \\
\hline
\end{tabular}

and pigweed $\mathrm{N}$ uptake over the duration of the study. While the accumulation of ${ }^{15} \mathrm{~N}$ into cereal rye shoots was confirmed, the magnitude of translocation of $\mathrm{N}$ from the soil was small, and was not a driving mechanism for either $\mathrm{N}$ immobilization or weed suppression.

Shoot biomass decomposition rates differed as a function of shoot application rate, with more rapid decomposition and $\mathrm{N}$ loss occurring with shoot application rates $\geq 5000 \mathrm{~kg} \mathrm{ha}^{-1}$ as compared to the $2000 \mathrm{~kg} \mathrm{ha}^{-1}$ rate. Cereal rye shoot biomass decomposition is a spatially differentiated process. Higher rates of decomposition occur at the soil surface, where spatial proximity and microclimate support residue colonization by soil microorganisms and arthropods, while upper residue layers remain protected from biological decomposition (Thorburn et al. 2001). Surface residues moderate soil temperature and increase soil water storage (Rathore et al. 1998; Cook et al. 2006). Available soil moisture exerts significant controls on decomposition rates (Fraser and Hockin 2013), and several studies have reported moisture, not temperature, as the dominant climatic control on decomposition (Murphy et al. 1998; Torres et al. 2005; Bontti et al. 2009). Soil moisture can also have effects on soil micro-arthropod communities (Wickings and Grandy 2013), which are influential during early stages of residue decomposition (Frouz et al. 2015; Soong and Nielsen 2016). Microarthropods can significantly increase decomposition rates by increasing detritus surface area through fragmentation, which fosters greater microbial colonization (Londoño-R et al. 2013). 
Fig. $4{ }^{15} \mathrm{~N}$ in cereal rye shoot biomass for each shoot application rate $\left(\mathrm{kg} \mathrm{ha}^{-1}\right)$. Points for each sampled day after planting are offset to reduce overlap

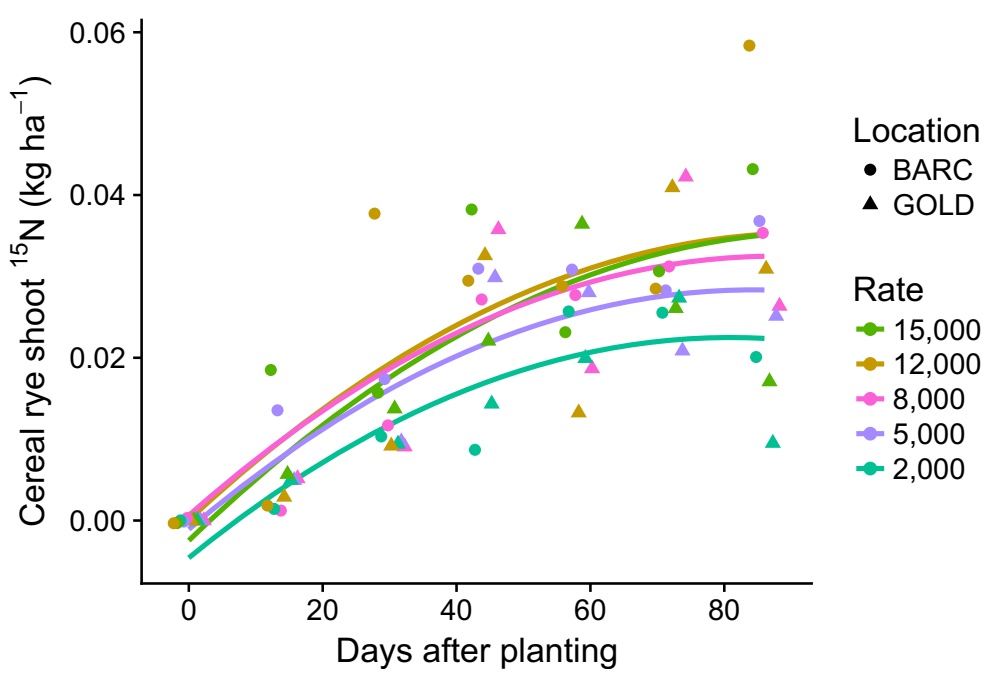

That said, it is also important to note that our experimental design controlled aspects of the soil environment that could have potentially differed if the quantities of aboveground biomass assigned to each microplot had actually been grown rather than applied as a residue treatment. For example, had $15,000 \mathrm{~kg} \mathrm{ha}^{-1}$ of cereal rye biomass been grown, the microplot soil environment would likely have been much drier upon cover crop termination compared with a microplot that grew $2000 \mathrm{~kg} \mathrm{ha}^{-1}$ of cereal rye biomass, due to differences in evapotranspiration. This may have impacted the observed rates of biomass decomposition across the different residue treatments.

The positive relationship between cover crop shoot biomass application rate and decomposition contrasts with results of previous studies that demonstrated a negative relationship between these factors (Parr and Papendick 1978; Stroo et al. 1989; Stott et al. 1990; Steiner et al. 1999; Thorburn et al. 2001). There are two potential reasons for this discrepancy: 1) differing experimental conditions; and 2) possible relationships between residue biomass and soil microenvironment.
Fig. 5 Proportional recovery of ${ }^{15} \mathrm{~N}$ in soybean and pigweed aboveground tissues and in cereal rye shoots for each shoot application rate

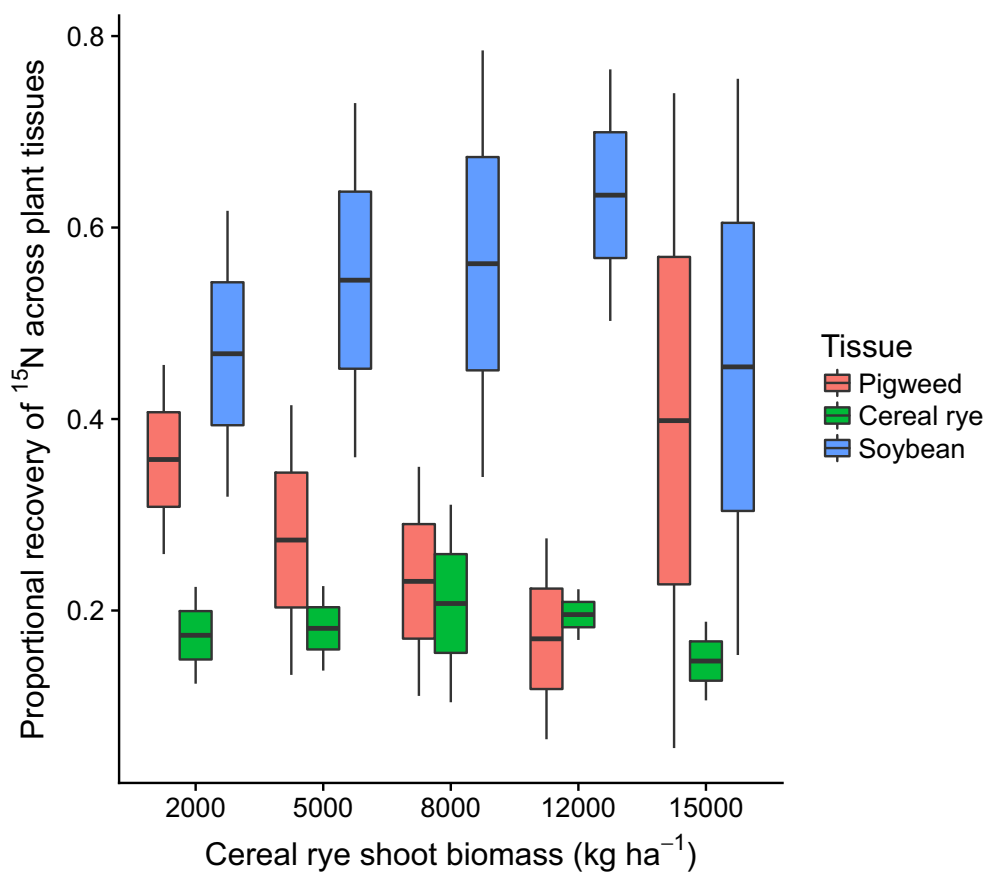


Fig. 6 Extractable soil inorganic $\mathrm{N}$ across six cereal rye shoot biomass rates including a 'roots only' rate and 'bare-ground' check $\left(\mathrm{kg} \mathrm{ha}^{-1}\right)$. Points for each sampled day after planting are offset to reduce overlap

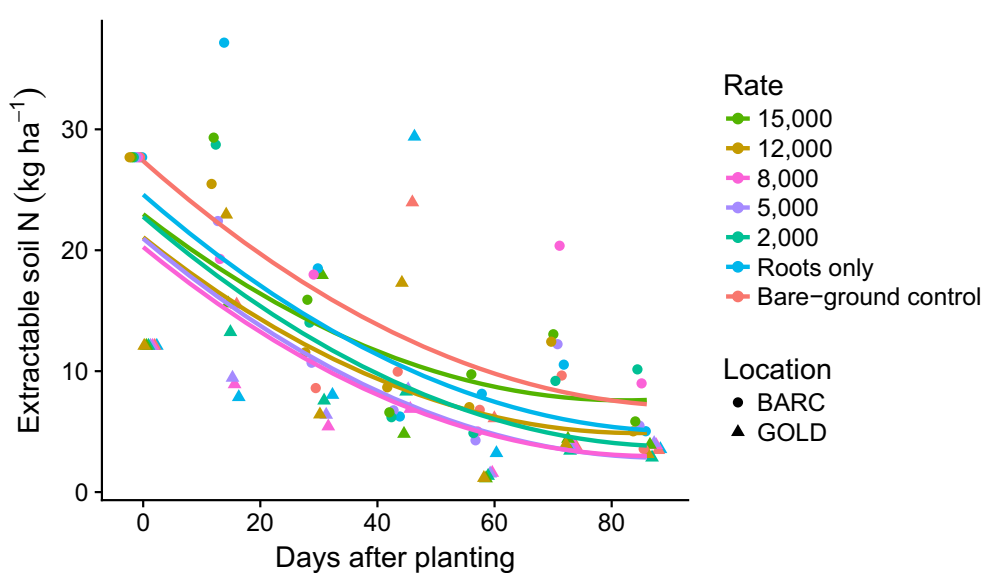

Other than Thorburn et al. (2001), none of the listed studies characterized decomposition rates of initial biomass applications greater than $8400 \mathrm{~kg} \mathrm{ha}^{-1}$, and all were conducted under dryland conditions. Thus, to the best of our knowledge, our experiment explores residue decomposition dynamics of biomass quantities orders of magnitude greater than most previous studies, and at levels considered necessary for effective weed suppression (Reberg-Horton et al. 2012; Mirsky et al. 2013). While Thorburn et al. (2001) modeled decomposition of high biomass rates $\left(10,000-20,000 \mathrm{~kg} \mathrm{ha}^{-1}\right)$ of sugar cane residue under varied climatic conditions, they did not account for the impact of initial residue mass on the size and properties of the actively decomposing, soilcontact residue layer.

Residue biomass rates can increase soil water storage (Cook et al. 2006; Mulumba and Lal 2008). Mulumba and Lal (2008) reported that wheat biomass rates ranging from 0 to $16 \mathrm{Mg} \mathrm{ha}^{-1}$ had logarithmic effects on field capacity moisture, where no gain in soil moisture retention was observed above $10 \mathrm{Mg} \mathrm{ha}{ }^{-1}$. Greater biomass rates can limit soil water recharge due to higher rates of precipitation interception and subsequent evaporation (Cook et al. 2006). Thus, the effect of shoot biomass on soil surface microclimate and residue decomposition may depend on precipitation.

In the present study, microplots were hand-irrigated, and water was introduced directly to the soil surface and decomposition layer, rather than being intercepted by the residue layer. It is possible that the observed increase in decomposition rate for the 8000, 12,000, and $15,000 \mathrm{~kg} \mathrm{ha}^{-1}$ shoot application rates was a result of differential desiccation of the surface residue after irrigation events. Microclimate conditions conducive for decomposition could have remained optimal for an increased period in the 12,000 and $15,000 \mathrm{~kg} \mathrm{ha}^{-1}$ shoot application rates, whereas rates less than or equal to $8000 \mathrm{~kg} \mathrm{ha}^{-1}$ may have experienced hastened declines in soil moisture (i.e., logarithmic decline), thereby diminishing the time frame for decomposition.

Cereal rye shoot $\mathrm{N}$ release coincided with the accumulation of ${ }^{15} \mathrm{~N}$ from surface soil into cereal rye shoots
Fig. 7 Pigweed tissue $\mathrm{N}$ across six cereal rye shoot biomass rates including a 'roots only' rate and 'bare-ground' check ( $\left.\mathrm{kg} \mathrm{ha}^{-1}\right)$. Points for each sampled day after planting are offset to reduce overlap

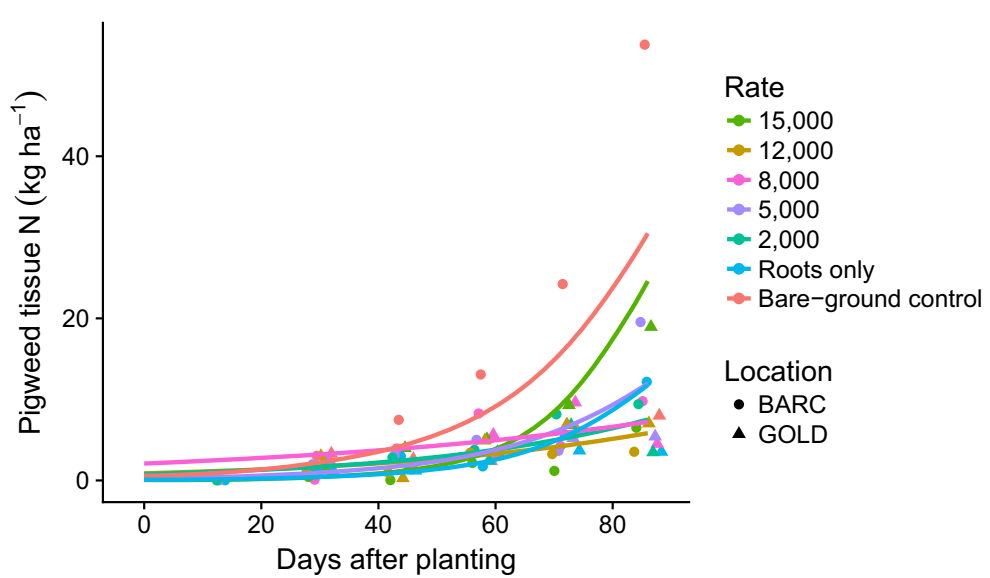


Fig. 8 Pigweed biomass across six cereal rye shoot biomass rates including a 'roots only' rate and 'bare-ground' check ( $\left.\mathrm{kg} \mathrm{ha}^{-1}\right)$. Points for each sampled day after planting are offset to reduce overlap

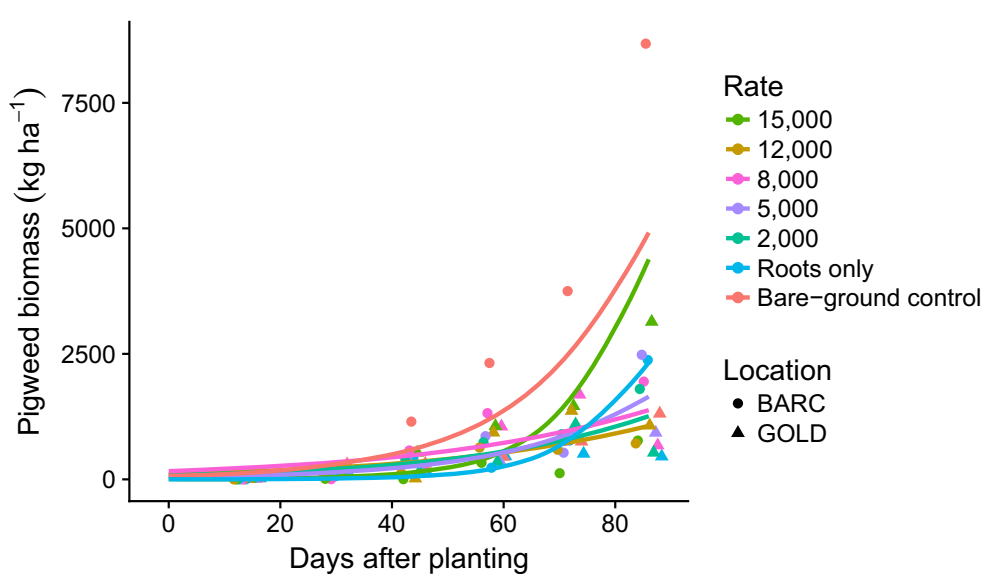

throughout the duration of the study, indicating a bidirectional movement of $\mathrm{N}$ between soil and surface residues. Similar quantities of ${ }^{15} \mathrm{~N}$ enrichment of cereal rye shoots were reported by Wells et al. (2017) under similar experimental conditions. Such movement has been characterized as evidence of direct translocation of soil $\mathrm{N}$ by fungal hyphae (Frey et al. 2000; Wells et al. 2017). In the present study, the quantity of ${ }^{15} \mathrm{~N}$ in cereal rye shoots at 86 DAP was lowest at the $2000 \mathrm{~kg} \mathrm{ha}^{-1}$ shoot application rate. This corresponds to the observed relationship between shoot application rate and decomposition, suggesting a decreased rate of fungal colonization, and a corresponding decrease in $\mathrm{N}$ translocation.

Despite evidence of $\mathrm{N}$ transfer into surface residues, the primary direction of $\mathrm{N}$ movement over time was from residues to soil. Cereal rye shoot $\mathrm{N}$ loss ranged from 5 to $30 \mathrm{~kg} \mathrm{~N} \mathrm{ha}^{-1}$, resulting in approximately $45 \%$ loss of residue $\mathrm{N}$ by $86 \mathrm{DAP}$, a finding consistent with other studies (Poffenbarger et al. 2015; Pantoja et al. 2016). Most studies examining decomposition of cover crop surface residues have considered the effects of residue quality rather than residue quantity on net $\mathrm{N}$ mineralization (Reberg-Horton et al. 2012; Lawson et al. 2012; Wells et al. 2013; Parr et al. 2014; Poffenbarger et al. 2015). Net $\mathrm{N}$ immobilization occurs when soil $\mathrm{N}$ availability poses limitations on microbial $\mathrm{C}$ acquisition. Net $\mathrm{N}$ immobilization is often expected when residue $\mathrm{C}: \mathrm{N}$ ratios are greater than 25 (RebergHorton et al. 2012). The C:N ratio of the shoots applied in the present study was 47 . Thus, it was anticipated that higher shoot application rates would encourage greater microbial demand for available $\mathrm{N}$, stimulating more net immobilization during decomposition. However, soil extractable $\mathrm{N}$ decreased similarly over time across all shoot application rates and bare-ground checks.

Residue-induced soil $\mathrm{N}$ immobilization was expected to suppress pigweed biomass and $\mathrm{N}$ uptake. Pigweed can be sensitive to N limitations (Shipley and Keddy 1988), and observed decreases in soil inorganic $\mathrm{N}$ from $19.3 \mathrm{~kg} \mathrm{~N}$ $\mathrm{ha}^{-1}$ at 0 DAP to $4.9 \mathrm{~kg} \mathrm{~N} \mathrm{ha}^{-1}$ at $86 \mathrm{DAP}$, averaged across
Fig. 9 Soybean biomass across six cereal rye shoot biomass rates including a 'roots only' rate and 'bare-ground' check $\left(\mathrm{kg} \mathrm{ha}^{-1}\right)$. Points for each sampled day after planting are offset to reduce overlap

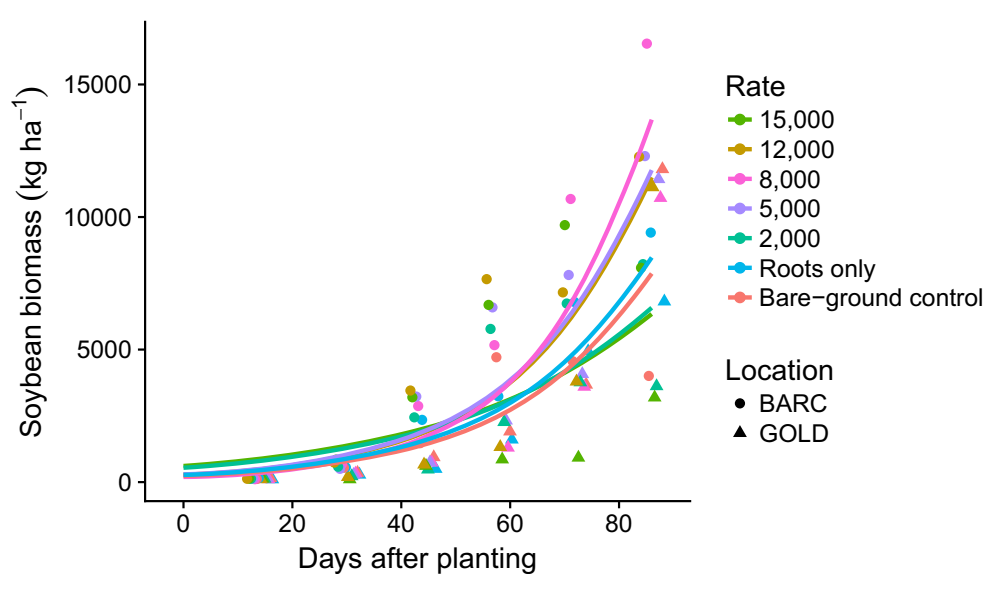


residue rates, was within the range of $\mathrm{N}$ limitation known to negatively influence summer annual broadleaf species such as pigweed (Wells et al. 2013). Pigweed biomass accumulation and $\mathrm{N}$ uptake were similar across all treatments containing cereal rye residue. However, greater pigweed $\mathrm{N}$ uptake and biomass accumulation values in bare-ground checks indicate that the presence of cereal rye roots prior to soybean planting had a suppressive effect on pigweed regardless of shoot application rate.

Roots are increasingly recognized as a primary source of soil $\mathrm{C}$ in agroecosystems, due largely to the preferential metabolism of root $\mathrm{C}$ by soil microorganisms (Rasse et al. 2005; Kätterer et al. 2011; Cates et al. 2016). The role of roots is amplified in no-till systems where shoots are not incorporated and decomposition is slowed due to lower oxygen levels. Under these conditions, roots are likely the primary sink for soil $\mathrm{N}$ in no-till systems (Gale and Cambardella 2000; Dinnes et al. 2002; Martinez-Feria et al. 2016). In contrast to the effects of cereal rye root and shoot biomass on pigweed growth and development, soybean biomass and $\mathrm{N}$ uptake were unaffected. This limited effect of cereal rye residue on soybean biomass and tissue $\mathrm{N}$ is attributed to the ability of soybean to fix $\mathrm{N}$.

\section{Conclusion}

This study provides some evidence for residue-induced $\mathrm{N}$ immobilization as a weed suppression mechanism in mulched no-till systems, with pigweed biomass and $\mathrm{N}$ uptake reduced in the presence of cereal rye roots and shoots. While $\mathrm{N}$ immobilization likely occurred via fungal $\mathrm{N}$ transportation to applied cereal rye shoots, soybean uptake was a stronger sink for soil inorganic N. Soybean growth and development was unaffected by soil $\mathrm{N}$ availability. The positive relationship between shoot application rate and decomposition was unexpected. Greater shoot application rates may have created favorable microclimates for microbial and micro-arthropod activity, thereby increasing decomposition by improving the microclimates throughout the shoot residue layer and detritusphere. Further research is needed to directly quantify the mechanisms by which cover crop driven $\mathrm{N}$ immobilization limits weed growth. While shoot biomass quantity did not impact weed suppression via $\mathrm{N}$ immobilization, cover crop species, tillage, and soil type may influence the magnitude of a nutritive mechanism for weed suppression and requires further investigation. This is important not only for developing more cost-effective weed control methods in organic farming systems, but also for developing integrated approaches to confronting the increasing prevalence of herbicide resistant weeds stemming from over-use of herbicides in conventional systems (Mortensen et al. 2012).

Open Access This article is distributed under the terms of the Creative Commons Attribution 4.0 International License (http:// creativecommons.org/licenses/by/4.0/), which permits unrestricted use, distribution, and reproduction in any medium, provided you give appropriate credit to the original author(s) and the source, provide a link to the Creative Commons license, and indicate if changes were made.

\section{References}

Ashford DL, Reeves DW (2003) Use of a mechanical roller-crimper as an alternative kill method for cover crops. Am J Altern Agric 18:37-45. https://doi.org/10.1079/AJAA200232

Beare MH, Hu S, Coleman DC, Hendrix PF (1997) Influences of mycelial fungi on soil aggregation and organic matter storage in conventional and no-tillage soils. Appl Soil Ecol 5:211219. https://doi.org/10.1016/S0929-1393(96)00142-4

Bernstein ER, Posner JL, Stoltenberg DE, Hedtcke JL (2011) Organically managed no-tillage rye-soybean systems: agronomic, economic, and environmental assessment. Agron J 103:1169-1179. https://doi.org/10.2134/agronj2010.0498

Bolinder MA, Janzen HH, Gregorich EG et al (2007) An approach for estimating net primary productivity and annual carbon inputs to soil for common agricultural crops in Canada. Agric Ecosyst Environ 118:29-42. https://doi.org/10.1016/j. agee.2006.05.013

Bontti EE, Decant JP, Munson SM et al (2009) Litter decomposition in grasslands of Central North America (US Great Plains). Glob Chang Biol 15:1356-1363. https://doi. org/10.1111/j.1365-2486.2008.01815.x

Burgess MS, Mehuys GR, Madramootoo CA (2002) Nitrogen dynamics of decomposing corn residue components under three tillage systems. Soil Sci Soc Am J 66:1350-1358. https://doi.org/10.2136/sssaj2002.1350

Cates AM, Ruark MD, Hedtcke JL, Posner JL (2016) Long-term tillage, rotation and perennialization effects on particulate and aggregate soil organic matter. Soil Tillage Res 155: 371-380. https://doi.org/10.1016/j.still.2015.09.008

Cook HF, Valdes GSB, Lee HC (2006) Mulch effects on rainfall interception, soil physical characteristics and temperature under Zea Mays L. Soil Tillage Res 91:227-235. https://doi.org/10.1016/j.still.2005.12.007

Derpsch R, Roth CH, Sidiras N, et al (1991) Controle da erosão no Paraná, Brasil: Sistemas de cobertura do solo, plantio direto e preparo conservacionista do solo. GTZ Eschborn,, Germany

Dinnes DL, Karlen DL, Jaynes DB et al (2002) Nitrogen management strategies to reduce nitrate leaching in tile-drained Midwestern soils. Agron J 94:153-171

Fraser LH, Hockin AD (2013) Litter decomposition rates of two grass species along a semi-arid grassland-forest ecocline. J Arid Environ 88:125-129. https://doi.org/10.1016/j. jaridenv.2012.07.009 
Frey SD, Elliott ET, Paustian K, Peterson GA (2000) Fungal translocation as a mechanism for soil nitrogen inputs to surface residue decomposition in a no-tillage agroecosystem. Soil Biol Biochem 32:689-698

Frouz J, Roubíčková A, Heděnec P, Tajovský K (2015) Do soil fauna really hasten litter decomposition? A meta-analysis of enclosure studies. Eur J Soil Biol 68:18-24. https://doi. org/10.1016/j.ejsobi.2015.03.002

Gale WJ, Cambardella CA (2000) Carbon dynamics of surface residue- and root-derived organic matter under simulated notill. Soil Sci Soc Am J 64:190-195. https://doi.org/10.2136 /sssaj2000.641190x

Grandy AS, Robertson GP (2007) Land-use intensity effects on soil organic carbon accumulation rates and mechanisms. Ecosystems 10:58-73

Håkansson I, Reeder RC (1994) Subsoil compaction by vehicles with high axle load — extent, persistence and crop response. Soil Tillage Res 29:277-304. https://doi.org/10.1016/01671987(94)90065-5

Hart SC, Firestone MK (1991) Forest floor-mineral soil interactions in the internal nitrogen cycle of an old-growth forest. Biogeochemistry 12:103-127. https://doi.org/10.1007 /BF00001809

Hart CS, Stark JM, Davidson EA (1994) Nitrogen mineralization, immobilization, and nitrification. In: Weaver RW (ed) Methods of soil analysis, part 2. Soil Sci. Society of America, Inc., Publisher, pp 985-1019

Holland EA, Coleman DC (1987) Litter placement effects on microbial and organic matter dynamics in an agroecosystem. Ecology 68:425-433. https://doi.org/10.2307/1939274

Jin K, Sleutel S, De Neve S et al (2008) Nitrogen and carbon mineralization of surface-applied and incorporated winter wheat and peanut residues. Biol Fertil Soils 44:661-665. https://doi.org/10.1007/s00374-008-0267-5

Kätterer T, Bolinder MA, Andrén O et al (2011) Roots contribute more to refractory soil organic matter than above-ground crop residues, as revealed by a long-term field experiment. Agric Ecosyst Environ 141:184-192

Keeney DR, Nelson DW (1982) Nitrogen - inorganic forms. In: Miller RH, Keeney DR (eds) Methods of soil analysis. Part 2. Chemical and Microbiological Properties. American Society of Agronomy and Soil Science Society of America, Madison, pp 643-698

Kornecki TS, Price AJ, Raper RL, Arriaga FJ (2009) New roller crimper concepts for mechanical termination of cover crops in conservation agriculture. Renew Agric Food Syst 24:165173. https://doi.org/10.1017/S1742170509002580

Kumar V, Brainard DC, Bellinder RR et al (2008) Suppression of Powell Amaranth ( Amaranthus Powellii ), shepherd â€ ${ }^{\mathrm{TM}} \mathrm{s}-$ purse ( Capsella Bursa- Pastoris ), and corn chamomile ( Anthemis Arvensis ) by buckwheat residues : role of nitrogen and fungal pathogens. Weed Sci 56:271-280. https://doi. org/10.1614/Ws-07-106.1

Kumar V, Brainard DC, Bellinder RR, Hahn RR (2011) Buckwheat residue effects on emergence and growth of weeds in winter-wheat (Triticum Aestivum) cropping systems. Weed Sci 59:567-573. https://doi.org/10.1614/WS-D11-00006.1

Lawson A, Fortuna AM, Cogger C et al (2012) Nitrogen contribution of rye-hairy vetch cover crop mixtures to organically grown sweet corn. Renew Agric Food Syst 28:59-69. https://doi.org/10.1017/S1742170512000014

Londoño-R LM, Tarkalson D, Thies JE (2013) In-field rates of decomposition and microbial communities colonizing residues vary by depth of residue placement and plant part, but not by crop genotype for residues from two Cry $1 \mathrm{Ab} \mathrm{Bt}$ corn hybrids and their non-transgenic isolines. Soil Biol Biochem 57:349-355. https://doi.org/10.1016/j.soilbio.2012.09.011

Martinez-Feria R, Dietzel R, Liebman M, Helmers MJ, Archontoulis SV (2016) Rye cover crop effects on maize: a system-level analysis. Field Crop Res 196:145-159

McBride WD, Greene C (2009) The profitability of organic soybean production. Renew Agric food Syst 24:276-284

McBride WD, Greene C, Foreman L, et al (2015) The profit potential of certified organic field crop production. U.S. Dept of Agric, Econ Res Serv, Washington, DC

Mirsky SB, Ryan MR, Curran WS et al (2012) Conservation tillage issues: cover crop-based organic rotational no-till grain production in the mid-Atlantic region, USA. Renew Agric Food Syst 27:31-40

Mirsky SB, Ryan MR, Teasdale JR et al (2013) Overcoming weed management challenges in cover crop-based organic rotational no-till soybean production in the eastern United States. Weed Technol 27:193-203. https://doi.org/10.1614/WT-D12-00078.1

Montgomery DR (2007) Soil erosion and agricultural sustainability. Proc Natl Acad Sci 104:13268-13272. https://doi. org/10.1073/pnas.0611508104

Mortensen DA, Egan JF, Maxwell BD et al (2012) Navigating a critical juncture for sustainable weed management. Bioscience 62:75-84

Mulumba LN, Lal R (2008) Mulching effects on selected soil physical properties. Soil Tillage Res 98:106-111. https://doi.org/10.1016/j.still.2007.10.011

Murphy KL, Klopatek JM, Klopatek CC (1998) The effects of litter quality and climate on decomposition along an elevantional gradient. Ecol Appl 8:1061-1071.

Pantoja JL, Woli KP, Sawyer JE, Barker DW (2016) Winter rye cover crop biomass production, degradation, and nitrogen recycling. Agron J. https://doi.org/10.2134/agronj2015.0336

Parr JF, Papendick RI (1978). Factor affecting the decomposition of crop residues by microorganisms. In: Oschwald WR (Ed). Crop residue management systems. Soil Sci. Soc. Am. Madison, WI. pp. 101-129.

Parr M, Grossman JM, Reberg-Horton SC et al (2014) Rollercrimper termination for legume cover crops in North Carolina: impacts on nutrient availability to a succeeding corn crop. Commun Soil Sci Plant Anal 45:1106-1119. https://doi.org/10.1080/00103624.2013.867061

Patel, S, Sawyer, JE, Lundvall, JP, and Hall, J. (2015) Root and shoot biomass and nutrient composition in a winter rye cover crop. In: $45^{\text {th }}$ North Central extension-industry soil fertility conference. 4-5 November 2015, Des Moines, IA, pp 113-118

Pinheiro J, Bates D, DebRoy S et al (2016) Nlme: linear and nonlinear mixed effects models. R Package Version 3:1-128

Poffenbarger HJ, Mirsky SB, Weil RR et al (2015) Biomass and nitrogen content of hairy vetch-cereal rye cover crop mixtures as influenced by species proportions. Agron J 107: 2069-2082. https://doi.org/10.2134/agronj14.0462

R Core Team (2016) R: A language and environment for statistical computing. Version 3.3.1 
Rasse DP, Rumpel C, Dignac M-F (2005) Is soil carbon mostly root carbon? Mechanisms for a specific stabilisation. Plant Soil 269:341-356

Rathore A, Pal A, Sahu K (1998) Tillage and mulching effects on water use, root growth and yield of rainfed mustard and chickpea grown after lowland rice. J Sci Food Agric 78:149-161

Reberg-Horton SC, Burton JD, Danehower DA et al (2005) Changes over time in the allelochemical content of ten cultivars of rye (Secale Cereale L.) J Chem Ecol 31:179-193. https://doi.org/10.1007/s10886-005-0983-3

Reberg-Horton SC, Grossman JM, Kornecki TS et al (2012) Utilizing cover crop mulches to reduce tillage in organic systems in the southeastern USA. Renew Agric Food Syst 27:41-48. https://doi.org/10.1017/S1742170511000469

Recous S, Robin D, Darwis D, Mary B (1995) Soil inorganic N availability: effect on maize residue decomposition. Soil Biol Biochem 27:1529-1538. https://doi.org/10.1016/0038-0717 (95)00096-W

Schomberg HH, Steiner JL, Unger PW (1994) Decomposition and nitrogen dynamics of crop residues: residue quality and water effects. Soil Sci Soc Am J 58:372-381. https://doi. org/10.2136/sssaj1994.03615995005800020019x

Schwendener CM, Lehmann J, de Camargo PB et al (2005) Nitrogen transfer between high- and low-quality leaves on a nutrient-poor Oxisol determined by $15 \mathrm{~N}$ enrichment. Soil Biol Biochem 37:787-794. https://doi.org/10.1016/j. soilbio.2004.10.011

Sheng Q, Hunt LA (1991) Shoot and root dry weight and soil water in wheat, triticale and rye. Can J Plant Sci 71:41-49

Shipley B, Keddy PA (1988) The relationship between relative growth rate and sensitivity to nutrient stress in twenty-eight species of emergent Macrophytes. J Ecol 76:1101-1110. https://doi.org/10.2307/2260637

Six J, Frey SD, Thiet RK, Batten KM (2006) Bacterial and fungal contributions to carbon sequestration in agroecosystems. Soil Sci Soc Am J 70:555-569

Soong JL, Nielsen UN (2016) The role of microarthropods in emerging models of soil organic matter. Soil Biol Biochem 102:37-39. https://doi.org/10.1016/j.soilbio.2016.06.020

Steiner JL, Schomberg HH, Unger PW, Cresap J (1999) Crop residue decomposition in no-tillage small-grain fields. Soil
Sci Soc Am J 63:1817-1824. https://doi.org/10.2136 /sssaj1999.6361817x

Stott DE, Stroo HF, Elliott LF et al (1990) Wheat residue loss from fields under no-Till Management. Soil Sci Soc Am J 54:92-98. https://doi.org/10.2136/sssaj1990.03615995005400010014x

Stroo HF, Bristow KL, Elliott LF et al (1989) Predicting rates of wheat residue decomposition. Soil Sci Soc Am J 53:91-99. https://doi.org/10.2136/sssaj1989.03615995005300010017x

Teasdale JR, Mohler CL (2000) The quantitative relationship between weed emergence and the physical properties of mulches. Weed Sci 48:385-392.

Thorburn PJ, Probert ME, Robertson FA (2001) Modelling decomposition of sugar cane surface residues with APSIMresidue. F Crop Res 70:223-232. https://doi.org/10.1016 /S0378-4290(01)00141-1

Torres PA, Abril AB, Bucher EH (2005) Microbial succession in litter decomposition in the semi-arid Chaco woodland. Soil Biol Biochem 37:49-54. https://doi.org/10.1016/j. soilbio.2004.04.042

Tu C, Louws FJ, Creamer NG et al (2006) Responses of soil microbial biomass and $\mathrm{N}$ availability to transition strategies from conventional to organic farming systems. Agric Ecosyst Environ 113:206-215

Webster TM, Simmons DB, Culpepper AS et al (2016) Factors affecting potential for palmer amaranth (Amaranthus Palmeri) suppression by winter rye in Georgia, USA. F Crop Res 192:103-109. https://doi.org/10.1016/j. fcr.2016.04.020

Wells MS, Reberg-Horton SC, Smith SN, Grossman JM (2013) The reduction of plant-available nitrogen by cover crop mulches and subsequent effects on soybean performance and weed interference. Agron J 105:539-545

Wells MS, Reberg-Horton SC, Mirsky SB et al (2017) In situ validation of fungal $\mathrm{N}$ translocation to cereal rye mulches under no-till soybean production. Plant Soil 410:153-165. https://doi.org/10.1007/s11104-016-2989-8

Wickings K, Grandy AS (2013) Management intensity interacts with litter chemistry and climate to drive temporal patterns in arthropod communities during decomposition. Pedobiologia (Jena) 56:105-112. https://doi.org/10.1016/j. pedobi.2013.01.001 